\title{
Prevalence study of Bovine viral diarrhea virus by evaluation of antigen capture ELISA and RT-PCR assay in Bovine, Ovine, Caprine, Buffalo and Camel aborted fetuses in Iran
}

\author{
Farhad Safarpoor Dehkordi
}

\begin{abstract}
Bovine viral diarrhea virus is a pestivirus in the family Flaviviridae that cause abortions and stillbirths in livestock and its traditional diagnosis is based on cell culture and virus neutralization test. In this study, for more sensitive, specific detection and determined the prevalence of virus in aborted Bovine, Ovine, Caprine, Buffalo and Camel fetuses the antigen capture ELISA and RT-PCR were recommended. From the total of 2173 aborted fetuses, 347 (15.96\%) and 402 (18.49\%) were positive for presence of Bovine viral diarrhea virus by antigen capture ELISA and RT-PCR respectively. Statistical analysis of data showed significant differences between ELISA and RT-PCR for detection of virus in aborted fetuses.

These results indicate a high presence of this pathogen in Iran and that RT- PCR is considerably faster and more accurate than ELISA for identification of Bovine viral diarrhea virus.

To our knowledge the Camels and Bovine are the most resistant and sensitive to Bovine viral diarrhea's abortions respectively and the prevalence of virus in Caprine is more than Ovine aborted fetuses. This study is the first prevalence report of Bovine viral diarrhea virus in aborted Bovine, Ovine, Caprine, Buffalo and Camel fetuses by evaluation of ELISA and RT-PCR in Iran.
\end{abstract}

Keywords: Prevalence study, Bovine viral diarrhea virus, antigen capture ELISA, RT-PCR, aborted fetuses, Iran

\section{Introduction}

Bovine viral diarrhea virus (BVDV) is a pestivirus in the family Flaviviridae and is closely related to classical swine fever and ovine Border disease viruses (Donis 1995) that cause Bovine Viral Diarrhea (BVD) in mammals including Antilocapridae, Bovidae, Camelidae, Cervidae, Giraffidae, Suidae, Tragulidae families and small ruminants (Grondahl et al. 2003; Nettleton 1990; Van Campen et al. 2001; Loken et al. 1995). Bovine viral diarrhea virus (BVDV) has world-wide distribution and causes various clinical syndromes in cattle including diarrhea, mucosal disease, reproduction disfunctions (abortion, teratogenesis, embryonic resorption, fetal mummification and stillbirth) and hemorrhagic

Correspondence: Dr.Farhads@yahoo.com

Young Researchers Club, Faculty of Veterinary Medcine, Islamic Azad University, Shahrekord Branch, Shahrekord, Iran syndrome (Coetzer and Tustin 2004; Passler et al. 2007; Baker 1995).

The immunotolerant cattle can shed the virus via secretion and excretion into the environment for a long time, thus being a major source of BVDV infections in herds (baker 1987). Therefore, BVD with these economic losses, need to accurate and sensitive diagnostic methods for rapid identification and elimination of persistent carriers in the herds.

Confirmation that an abortion is caused by BVDV is often difficult to establish (Ruth 1987). In past, the most common method was an isolation of virus in cell cultures but it was difficult, time consuming and lengthy process that requires experienced technicians.

The serological methods such as Enzyme-linked immunosorbent assay (ELISA) usually employed for diagnosis BVDV in clinical samples (Entrican et al. 1995) but at these years several molecular methods like 
reverse transcriptase polymerase chain reaction (RTPCR) are use extremely to detection of BVD viral RNA for diagnostic purposes (Kim and Dobovi 2003; Gilbert et al. 1999).

The two fold purpose of this current study were to detection of BVDV by evaluation of antigen capture ELISA and RT-PCR assay in aborted fetuses and determined the prevalence rate of this virus in aborted Bovine, Ovine, Caprine, Buffalo and Camel fetuses samples in Iran. The positive aborted fetuses for BVD were studied for presents of gross lesion.

\section{Materials and methods \\ Samples}

A total of 2173 aborted fetuses including 620 Bovine, 525 Ovine, 442 Caprine, 372 Buffalo and 214 Camel were collected from 1012 commercial herds of various area of Iran in autumn of 2010 (Table 1). All samples had only abomasal contents of aborted fetuses those collected in strile conditions and sent under refrigeration to the labrotary as soon as possible. Samples were stored at $-20^{\circ} \mathrm{C}$ until processing.

\section{Antigen capture ELISA}

All samples were tested using commercial BVDV Antigen Test Kit/Serum Plus (HerdChek, IDEXX Laboratories, Westbrook, ME, USA), in which microtitre plates were coated with anti- Erns monoclonal antibodies. The kit is based on the detection of the Erns (gp44-48) glycoprotein of the BVD virus. The abomasal content samples were diluted (1:1) by wash solution. Fifty $\mu$ l of sample was loaded into wells and incubated for 2 hours at $37^{\circ} \mathrm{C}$. The reaction was terminated by the addition of $100 \mu \mathrm{l}$ of stop solution to each well and finally the absorbance at $450 \mathrm{~nm}$ was monitored in ELISA reader (BIO-TEK Instruments, Inc. Winooski, VT, USA). The result could be read visually where the OD was measured at450 nm. Positive and negative control were used as indicated in the kit.

The presence or absence of BVDV antigen in the sample is determined by the corrected OD value $(\mathrm{S}-\mathrm{N})$ for

\begin{tabular}{|c|c|c|c|c|c|}
\hline \multirow[t]{2}{*}{ Provinces } & \multicolumn{5}{|c|}{ No. of samples } \\
\hline & Bovine & Ovine & Caprine & Buffalo & Camel \\
\hline Tehran & 274 & 100 & 53 & 165 & 33 \\
\hline Isfahan & 188 & 76 & 148 & 70 & 81 \\
\hline Kerman & 83 & 152 & 102 & 25 & 70 \\
\hline Khorasan & 75 & 197 & 139 & 112 & 30 \\
\hline Total & 620 & 525 & 442 & 372 & 214 \\
\hline
\end{tabular}

Samples were collected randomly in autumn of 2010 . each sample was considered as follow:

$$
\mathrm{S}-\mathrm{N}=\text { Samples A450 - } \mathrm{NCx}^{-}
$$

Samples with S-N values less or equal to 0.3 were classified as negative and samples with $\mathrm{S}-\mathrm{N}$ values higher than 0.3 were classified as positive for BVDV antigen. In this study the $\mathrm{NCx}^{-}$is negative control.

\section{RNA extraction}

RNA purification was performed using the $\mathrm{RNX}^{\mathrm{TM}}$ - Plus Kit (Sinagen, Iran) according to the manufacturer's instructions. Briefly 100-150 $\mu$ l of viral suspension (abomasal contents and water control) were mixed with 1 $\mathrm{ml}$ of RNX and left for at least $5 \mathrm{~min}$ at $4^{\circ} \mathrm{C}$. After the addition of $200 \mu \mathrm{l}$ chloroform and mixing, the liquid was clarified by centrifugation at $12,000 \times \mathrm{g}$ for $15 \mathrm{~min}$ at $4{ }^{\circ} \mathrm{C}$. The supernatant was transferred to a new tube and mixed with an equal volume of isopropanol followed by centrifugation at $12,000 \mathrm{~g}$ for $15 \mathrm{~min}$ at $4{ }^{\circ} \mathrm{C}$. The pellet was washed with $1 \mathrm{ml}$ of $70 \%$ ethanol. Finally, RNA was eluted in $50 \mu \mathrm{l}$ of $1 \mathrm{mM}$ RNase free EDTA.

\section{RT-PCR assay}

The forward primer sequence is 5'- CAT- GCC-CCTAGT-AGG-ACT-AGC-3', and the reverse primer sequence is 5'- TCA-ACT-CCA-TGT-GCC-ATG-TAC-3', which is use for BVDV screen in abomasal contents of aborted fetuses. All oligonucleotide primers were obtained from a commercial source (Cinna Gen, Iran). Total RNA $(3 \mu \mathrm{l})$ was mixed with $1.5 \mu \mathrm{l} \mathrm{ml}$ of reverse primer $(10 \mu \mathrm{M} /$ $\mu \mathrm{l}$ ) and incubated at $70^{\circ} \mathrm{C}$ for $5 \mathrm{~min}$ followed by chilling on ice. The rest of the reaction mixture contained $4 \mu \mathrm{l}$ of $5 \times$ first strand buffer, $2 \mu \mathrm{l}$ of dNTPs $(10 \mathrm{mM}), 20 \mathrm{U}$ of RNasin $(20 \mathrm{U} / \mu \mathrm{l}), 200 \mathrm{U}(200 \mathrm{U} / \mu \mathrm{l})$ of Moloney Murine Leukemia Virus (M-MuLV) (Fermentas) and $7.5 \mu \mathrm{l} \mathrm{d-H20}$ was added, followed by an incubation at $42^{\circ} \mathrm{C}$ for $60 \mathrm{~min}$ cDNA synthesis was terminated by incubation at $70^{\circ} \mathrm{C}$ for $10 \mathrm{~min}$. PCR was performed in a $25 \mu \mathrm{l}$ reaction mix. The final concentration of the reagent was as follows: PCR buffer $(1 \times$ time) (Cinagen, Iran), dNTP $0.2 \mathrm{mM}), \mathrm{MgCl} 2$ (1.5 $\mathrm{mM})$, each primer $(0.5 \mu \mathrm{M})$, Taq DNA polymerase (0.625). Reactions were performed in an automated thermal cycler (Bio-Rad gradient Thermal Cycle). Cycle parameters for PCR were as follows: one cycle at $95^{\circ} \mathrm{C}$ for 5 min followed by thirthy five cycles in 3 continous phases including $94^{\circ} \mathrm{C}$ for $30 \mathrm{sec}, 55^{\circ} \mathrm{C}$ for $100 \mathrm{sec}$, and $72^{\circ} \mathrm{C}$ for 2 min, and finally terminated by a single cycle of a final extention at $72^{\circ} \mathrm{C}$ for $10 \mathrm{~min}$.

\section{Gel electrophoresis}

The RT-PCR-amplified products were examined by electrophoresis in a $2 \%$ agarose gel, stained with a $1 \%$ solution of ethidium bromide, and examined under UV 
illumination. In this study, A negative control (sterile water), and a positive control RNA from BVDV (Cinna Gen, Iran), were included in each amplification run.

\section{Statistical analysis}

Data were transferred to Microsoft Excel spreadsheet (Microsoft Corp., Redmond, WA, USA) for analysis. Using SPSS 18.0 statistical software (SPSS Inc., Chicago, IL, USA), ANOVA test analysis were performed and differences were considered significant at values of $\mathrm{P}<$ 0.05 .

\section{Results}

In this study a total of 2173 abomasal content samples of aborted fetuses including 620 Bovine, 525 Ovine, 442 Caprine, 372 Buffalo and 214 Camel from 1012 commercial herds of various area of Iran were tested for presence of BVDV by evaluation of antigen capture ELISA and RT-PCR assay.

Data from antigen capture ELISA were studied and quality of RNA extracted after agarose gel electrophoresis from abomasal contents of aborted fetuses were observed and all were accepted and diagnosed suitable for RT-PCR assay.

Results indicated that from a total of 2173 abomasal content of aborted fetus samples, 347 (15.96\%) and 402 (18.49\%) were positive for presence of BVDV by antigen capture ELISA and RT-PCR assay respectively. Serological and molecular results indicate that the frequency of BVDV in aborted Bovine, Ovine, Caprine, Buffalo and Camel fetuses are shown in table 2.

Statistical analysis of data showed significant differences about $\mathrm{P}<0.01$ between antigen capture ELISA and RT-PCR for detection of BVDV in abomasal

Table 2 Frequency of Bovine viral diarrhea virus in aborted bovine, ovine, caprine, buffalo and camel fetuses by evaluation of antigen capture ELISA and RT-PCR methods in Iran

\begin{tabular}{lccc}
\hline Species & No. of samples & $\begin{array}{c}\text { Antigen capture } \\
\text { ELISA (\%) }\end{array}$ & RT-PCR (\%) \\
\hline Bovine & 620 & 111 & 127 \\
& & $(17.90)$ & $(20.48)$ \\
\hline Ovine & 525 & 74 & 74 \\
& & $(14.09)$ & $(16.74)$ \\
\hline Caprine & 442 & 71 & 93 \\
& & $(16.06)$ & $(17.71)$ \\
\hline Buffalo & 372 & 63 & 76 \\
& & $(16.93)$ & $(20.43)$ \\
\hline Camel & 214 & 27 & 32 \\
& & $(12.61)$ & $(14.95)$ \\
\hline Total & 2173 & 347 & 402 \\
& & $(15.96)$ & $(18.49)$ \\
\hline
\end{tabular}

Table show that the RT-PCR method has a higher accuracy than antigen capture ELISA to detection of BVD virus. contents of aborted Bovine, Ovine, Buffalo and Camel fetuses and $\mathrm{P}<0.05$ between ELISA and RT-PCR for detection of BVDV in abomasal contents of aborted Caprine fetuses.

In additional to above, results showed significant differences about $\mathrm{P}<0.01$ between presence of BVDV in Camel aborted fetuses with Bovine and Buffalo and $\mathrm{P}<$ 0.05 between presence of BVDV in Bovine with Ovine and Caprine aborted fetuses, by using each of two diagnostic methods. The observed difference between aborted fetuses and control group is significant $(\mathrm{P}<0.05)$. The $\mathrm{S}-\mathrm{N}$ values that were obtained after antigen capture ELISA have significant differences about $\mathrm{P}<0.05$ between infected and noninfected aborted fetuses by BVDV.

Therefore, we can conclude that the abortion is a direct consequence of BVDV infection in the herds studied.

This present study showed that the RT-PCR is more accurate than antigen capture ELISA to detection of BVDV in aborted fetuses. Therefore, the prevalence rate of BVDV in aborted fetuses of Iran was estimated 18.49\% (402 positive from 2173 samples).

Using from the negative and positive controls in all RT-PCR testing that were performed in this study, cause to all of the samples that were reported positive for presences of BVDV, had a sufficient accuracy and practical diagnostic value.

Figeres show a typical example of RT-PCR results for representative isolates of BVDV (Figure 1).

Our results showed that BVDV infection present widely in aborted Bocine, Ovine, Caprine, Buffalo and camel fetuses in the herds of Iran. The Camel is the

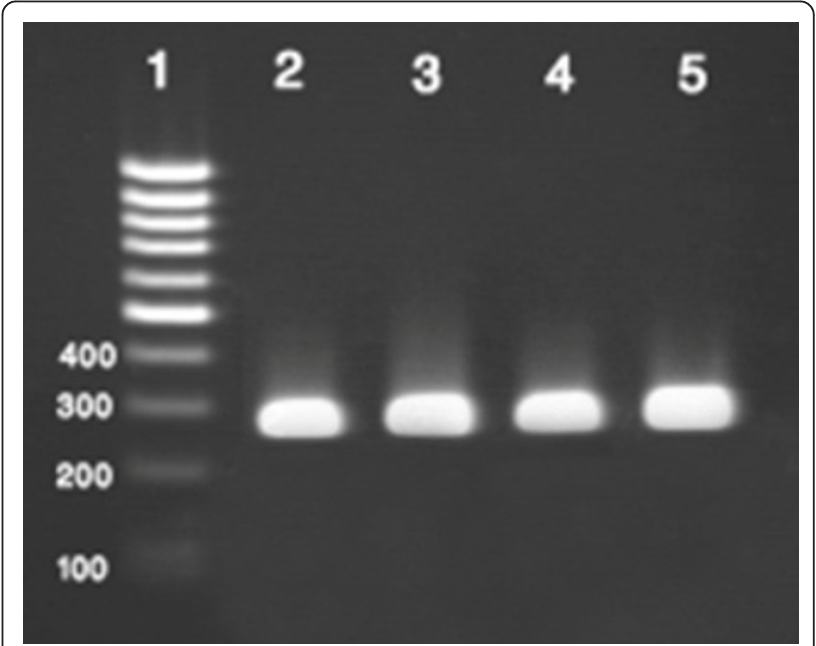

Figure 1 Electrophoresis of PCR products of BVDV genome obtained by RT-PCR on $2 \%$ agarose gel electrophoresis. 1 is 100 bp ladder, 2-4 is positive sample and 5 is positive control. In this study the length of RT-PCR product was $290 \mathrm{bp}$. 
most resistant and the Bovine is the most sensitive to BVDV's abortion.

Our results showed that the prevalence of BVDV in Caprine is more than Ovine aborted fetuses.

\section{Discussion}

There are many factors those causes abortion in livestock but the causes of animal abortion are unknown in more than $50 \%$ of the cases. BVD is one of the most important infectious diseases which associated with infertility and abortion. Placental changes produced by BVDV could allow other pathogenic organisms to cross the fetal placenta barrier (Murray 1991).

BVD cause significant economic losses in the livestock industry in Iran. The prevalence of BVD in Iran has been mainly reported on the basis of the detection of antibody against BVDV. In early investigations a range of $20-90 \%$ of BVD incidence has been reported (Mirshamsy et al. 1970). In a study on slaughtered cattle in Tehran province, $58.51 \%$ of animals were found to be seropositive (Kargar et al. 1995). In a later survey of the cattle population in Iran, 3000 serum samples were tested and results showed that about $39.6 \%$ of young animals were seropositive. The prevalence of antibody and the proportion of seropositive animals rose markedly with age up to $62 \%$ (Sedighi-nejad 1996). Therefore, following control programs in Iran, the prevalence of BVD from 20-90\% in 1970 (Mirshamsy et al. 1970) and $62 \%$ in 1996 (Sedighi-nejad 1996), decrease to $18.49 \%$ in 2011 (this present study).

In the majority of cases, confirmation that an abortion is caused by BVDV is difficult to establish (Ruth 1987) but this present study introduced antigen capture ELISA and RT-PCR assay as an accurate and sensitive diagnostic methods that can detect BVDV virus in abomasal contents of aborted fetuses. Our results indicated that the molecular method was more accurate than antigen capture ELISA that was similar to previous study (Horner et al. 1995).

Several methods for ELISA for antigen detection have been published (Vanderheijden et al. 1993; Cornish et al. 2005; Entrican et al. 1995) and a number of commercial kits are available. Most are based on the sandwich ELISA principle, with a capture antibody bound to the solid phase, and a detector antibody conjugated to a signal system, such as peroxidase. The new generation of antigen-capture ELISAs (ERNS capture ELISAs) is able to detect BVD antigen in blood as well as in plasma or serum samples. Our antigen capture ELISA is able to detect BVDV antigen in abomasal content of aborted fetuses. Due to transient viraemia, the antigen ELISA appears to be less useful for virus detection in acute BVD infections. In addition to above, our results showed that the antigen capture ELISA for detecting BVDV is technically time-consuming and labor-intensive than RT-PCR assay.

The previous study that comparison of RT-PCR with ELISA and cell culture immunoperoxidase tests for the detection of ruminant pestivirus infections revealed that RT-PCR is more sensitive than the other tests (Horner et al. 1995). The RT-PCR method can be adapted to the detection of BVD viral RNA for diagnostic purposes (Kim and obovi 2003, Letellier and Kerkhofs 2003). This may have a special value where low-level virus contamination is suspected, for example in biological products such as vaccines (sadeghi-nejad 1996).

Since, RT-PCR assay has been developed for the detection of BVDV in a wide variety of clinical samples such as formalin fixed paraffin embedded tissue sections (Gilbert et al. 1999), milk (Drew et al. 1999), blood (Hamel et al. 1995), follicular fluid (Kim and obovi 2003), Serum (Kosinova et al. 2007), skin samples (Passler et al. 2010), Ear notch (Kennedy et al. 2006) and in all of these studies RT-PCR has been introduced as an accurate and sensitive method to detection of BVDV. In these years many countries have accepted PCR as an accurate, fast and official assay to detection of various diseases such as BVD. Studies indicated that PCR is an accurate assay to detection of BVD's closely related disease such as Brucellosis (Buyukcangaz et al. 2011), Infectious Bovine Rhinotracheitis (IBR) (Takiuchi et al. 2005) and Leptospirosis (Richtzenhain et al. 2002) in clinical samples like aborted fetuses.

This present study showed that our RT-PCR test can be used as a commercial RT-PCR kit to detection of BVDV in various clinical samples.

In all RT-PCR assays it is important to adopt a nucleic acid extraction method which removes inhibitory factors and recovers most of the desired RNA.

BVD is a world-wide disease and reported from many sites of the world. The prevalence of BVDV in Bovine of Iran (20.48\%) is higher than Argentina (1.69\%) (Campero et al. 2003), Greek (14\%) (Billinis et al. 2005) And India (17.31\%\%) (Sudharshana et al. 1999) But is lower than Northern Portugal (35\%) (Niza-Ribeiro et al. 2005) and Turkey (23.07\%) (Seyyal et al. 2002).

The previous study on Ovine aborted fetuses showed that placenta, heart, thymus and brain of fetuses are the most reliable tissues for BVDV antigen detection (Lamm et al. 2009).

To our knowledge there is no published data on prevalence of infected Bovine, Ovine, Caprine, Buffalo and Camel aborted fetuses with BVDV in Iran. So this study is the first report of direct identification of BVD virus by evaluation of antigen capture ELISA and RT-PCR in aborted Bovine, Ovine, Caprine, Buffalo and Camel fetuses in Iran. 
Unfortunately, with all the precautions in this infection disease throughout the world it is not only still fully eradicated but also, it has a high prevalence in some areas like Iran (18.49\% in this study). Aborted fetuses and reproductive discharge plays important roles in spread of disease and rapi, sensitive and trustful diagnostic methods can help to control disease.

The studies on Buffaloes and Camels are less than Bovine, Ovine and Caprine and this present study showed that the BVDV infection is one of the most prevalent causes of abortion in Buffaloes, Camels (in less amount) and as expected in Bovine. Disease is more prevalent in Caprine in contrast to Ovine. In the other hands, this present study showed that in addition to Bovine, BVDV can be a factor that cause abortion in Ovine, Caprine, Buffalo and Camel.

\section{Abbreviations}

ELISA: enzyme linked immune sorbent assay; RT-PCR: reverse transcriptase polymerase chain reaction; BVDV: bovine viral diarrhea virus; ANOVA: analysis of variance; RNX: RNA extraction.

\section{Acknowledgements}

We would like to thank the assistance and support of Hasan Momtaz from faculty of veterinary medicine, department of microbiology, Islamic Azad University of Shahrekord Branch, Shahrekord, Iran and gratefully thanks the Young Researchers Club of Islamic Azad University of Shahrekord Branch, Shahrekord, Iran.

\section{Authors' contributions}

All works such as collection of samples, RNA extraction, ELISA and RT-PCR performing, statistical analysis and writing of manuscript was done by Farhad Safarpoor Dehkordi.

\section{Competing interests}

The authors declare that they have no competing interests.

Received: 9 September 2011 Accepted: 21 October 2011 Published: 21 October 2011

\section{References}

Baker JC (1995) The clinical manifestations of bovine viral diarrhea infection. Vet Clin N Am-Food A 11:425-445

Baker JC (1987) Bovine viral diarrhea virus: a review. JAVMA 190:1449-1458

Billinis C, Leontides L, Amiridis GS, Spyrou V, Kostoulas P, Sofia M (2005)

Prevalence of BVDV infection in Greek dairy herds. Prev vet med 72:75-79. doi:10.1016/j.prevetmed.2005.05.011.

Buyukcangaz E, Sen A, Carli KT, Kahya S (2011) Comparison of direct culture versus PCR for the detection of Brucella in aborted fetuses of cattle and sheep in Turkey. Vet Rec 168:430. doi:10.1136/vr.c7003.

Campero CM, Moore DP, Odeón AC, Cipolla AL, Odriozola E (2003) Aetiology of Bovine Abortion in Argentina. Vet Res Commun 27:359-369

Coetzer JAW, Tustin RC (2004) Bovine viral diarrhea and mucosal disease. In: Potgieter LND (ed) Infectious disease of livestock. 2nd edition, pp. 946

Cornish TE, Van Olphen AL, Cavender JL, Edwards JM, Jaeger PT, Vieyra LL, Woodard LF, Miller DR, O'toole D (2005) Comparison of ear notch immunohistochemistry, ear notch antigencapture ELISA, and buffy coat virus isolation for detection of calves persistently infected with bovine viral diarrhea virus. J Vet Diagn Invest 17:110-117. doi:10.1177/ 104063870501700203.

Donis RO (1995) Molecular biology of bovine viral diarrhea virus and its interactions with the host. Veterinary clinics of north America 11:393-423

Drew TW, Yapp F, Paton DJ (1999) The detection of bovine viral diarrhoea virus in bulk milk samples by the use of a single-tube RT-PCR. Vet Microbiol 64:145-154. doi:10.1016/S0378-1135(98)00266-1.
Entrican G, Dand A, Nettleton PF (1995) A double monoclonal antibody ELISA for detecting pestivirus antigen in the blood of viraemic cattle and sheep. Vet Microbiol 43:65-74. doi:10.1016/0378-1135(94)00081-7.

Gilbert SA, Burton KM, Prins SE, Deregt D (1999) Typing of bovine viral diarrhea viruses directly from blood of persistently infected cattle by multiplex PCR. J Clin Microbiol 37:2020-2023

Grondahl C, Uttenthal A, Houe H, Rasmussen TB, Hoyer MJ, Larsen LE (2003) Characterisation of a pestivirus isolated from persistently infected mousedeer (Tragulus javanicus). Arch Virol 148:1455-1463. doi:10.1007/s00705-003-01309.

Hamel AL, Wasylyshen MD, Nayar GP (1995) Rapid Detection of Bovine Viral Diarrhea Virus by Using RNA Extracted Directly from Assorted Specimens and a One-Tube Reverse Transcription PCR Assay. J Clin Microbiol 33:287-291

Horner GW, Tham KM, Orr D, Ralston J, Rowe S, Houghton T (1995) Comparison of an antigen capture enzyme-linked assay with reverse transcription polymerase chain reaction and cell culture immunoperoxidase tests for the diagnosis of ruminant pestivirus infections. Vet Microbiol 43:75-84. doi:10.1016/0378-1135(94)00080-G.

Kargar R, Ahuraei P, Hesami M, Khedmati K, Gholami MR, Kazemi A (1995) Reporting presence and prevalence of BVD/MD in cattle farms around Tehran. J Pajohesh va Sazandegi 28:112-116

Kennedy JA, Mortimer RG, Powers B (2006) Reverse transcription-polymerase chain reaction on pooled samples to detect bovine viral diarrhea virus by using fresh ear-notch-sample supernatants. J Vet Diagn Invest 18:89-93. doi:10.1177/104063870601800113.

Kim SG, Dubovi EJ (2003) A novel simple one-step single-tube RT-duplex PCR method with an internal control for detection of bovine viral diarrhoea virus in bulk milk, blood, and follicular fluid samples. Biologicals 31:103-106. doi:10.1016/S1045-1056(03)00023-X.

Kosinova E, Psikal I, Robesova B, Kovarcik K (2007) Real-time PCR for quantitation of bovine viral diarrhea virus RNA using SYBR Green I fluorimetry. Vet MedCzech 52:253-261

Lamm CG, Broaddus CC, Holyoak GR (2009) Distribution of bovine viral diarrhea virus antigen in aborted fetal and neonatal goats by immunohistochemistry. Vet pathol 46:54-58. doi:10.1354/vp.46-1-54.

Letellier C, Kerkhofs P (2003) Real-time PCR for simultaneous detection and genotyping of bovine viral diarrhea virus. J Virol Methods 114:21-27. doi:10.1016/j.jviromet.2003.08.004.

Loken T (1995) Ruminant pestivirus infections in animals other than cattle and sheep. Vet Clin North Am Food Anim Pract 11:597-614

Mackay IM (2004) Real-time PCR in the microbiology laboratory. Clin Microbiol Infec 10:190-212. doi:10.1111/j.1198-743X.2004.00722.x.

Mirshamsy H, Shafyi A, Bahrami (1970) The occurrence of bovine virus diarrhea/ Mucosal disease in Iran. Arch Razi 22:197-201

Murray RD (1991) Lesions in aborted bovine fetuses and placenta associated with bovine viral diarrhoea virus infection. Arch Virol 3:217-224

Nettleton PF (1990) Pestivirus infections in ruminants other than cattle. Rev Sci Tech 9:131-150

Niza-Ribeiro J, Pereira A, Souza J, Madeira H, Barbosa A, Afonso C (2005) Estimated BVDV-prevalence, -contact and -vaccine use in dairy herds in Northern Portugal. Prev vet med 72:81-85. doi:10.1016/j. prevetmed.2005.06.005.

Passler T, Ditchkoff SS, Givens MD, Brock KV, Deyoung RW, Walz PH (2010) Transmission of bovine viral diarrhea virus among white-tailed deer (Odocoileus virginianus). Vet Res 41:20. doi:10.1051/vetres/2009068.

Passler T, Walz PH, Ditchkoff SS, Givens MD, Maxwell HS, Brock KV (2007) Experimental persistent infection with bovine viral diarrhea virus in whitetailed deer. Vet Microbiol 122:350-356. doi:10.1016/j.vetmic.2007.01.028.

Richtzenhain LJ, Cortez A, Heinemann MB, Soares RM, Sakamoto SM, Vasconcellos SA, Higa ZM, Scarcelli E, Genovez ME (2002) A multiplex PCR for the detection of Brucella spp. and Leptospira spp. DNA from aborted bovine fetuses. Vet Microbiol 87:139-147. doi:10.1016/S0378-1135(02)00049-4.

Ruth GR (1987) Bovine viral diarrhea: a difficult infection to diagnose. Vet Med $81: 870-874$

Sedighi-nejad S (1996) A survey on BVD/MD in Iran. J Pajohesh va Sazandegi 30:128-131

Seyyal AK, Ibrahim FIRAT, Hakan Bozkurt H, Veli G, Kemal AK (2002) The Prevalence of Bovine Viral Diarrhoea Virus (BVDV) Infections in Cattle and Existence of Persistently Infected Cattle in the Trakya Region. Turk J Vet Anim Sci 26:245-248 
Sudharshana KJ, Suresh KB, Rajasekhar M (1999) Prevalence of bovine viral diarrhoea virus antibodies in India. Rev sci tech Off int Epiz 18:667-671

Takiuchi E, Médici KC, Alfieri AF, Alfieri AA (2005) Bovine herpesvirus type 1 abortions detected by a semi-nested PCR in Brazilian cattle herds. Res in Vet Sci 79:85-88. doi:10.1016/j.rvsc.2004.11.005.

Van Campen H, Froelich K, Hofmann M (2001) Pestivirus infections. in: Williams ES, Barker IK (Eds) Infectious diseases of wild mammals, lowa State University Press, Ames, pp 232-244

Vanderheijden N, Demoerlooze L, Vanderbergh D, Chappuis G, Renard A, Lecomte C (1993) Expression of the bovine viral diarrhoea virus osloss-p80 protein: its use as ELISA antigen for cattle serum antibody detection. J Gen Virol 74:1427-1431. doi:10.1099/0022-1317-74-7-1427.

Vilcek S, Herring AJ, Herring JA, Nettleton PF, Lowings JP, Paton DJ (1994) Pestiviruses isolated from pigs, cattle and sheep can be allocated into at least three genegroups using polymerase chain reaction and restriction endonuclease analysis. Arch Virol 136:309-323. doi:10.1007/BF01321060.

doi:10.1186/2191-0855-1-32

Cite this article as: Safarpoor Dehkordi: Prevalence study of Bovine viral diarrhea virus by evaluation of antigen capture ELISA and RT-PCR assay in Bovine, Ovine, Caprine, Buffalo and Camel aborted fetuses in Iran.

AMB Express 2011 1:32

\section{Submit your manuscript to a SpringerOpen ${ }^{\mathcal{O}}$ journal and benefit from:}

- Convenient online submission

- Rigorous peer review

- Immediate publication on acceptance

- Open access: articles freely available online

- High visibility within the field

- Retaining the copyright to your article

Submit your next manuscript at $\gg$ springeropen.com 